\title{
DIE FORMALISME IN DIE WISKUNDE
}

(Inougurele Rede gelewer by die aanvaarding van 'n professoraat in die Wiskunde en Toegepaste Wiskunde aan die P.U. vir C.H.O., deur

dr. H. J. Schutte, op Vrydag 8 Junie 1962).

Hooggeleerde Rektor van die Potchefstroomse Universiteit vir C.H.O., Hooggeagte here lede van die Raad van hierdie Universiteit, Hooggeleerde here Professore, dames en here Lektore,

Dames en here studente, Dames en here,

Die kernprobleem in die Wyshegeerte van die Wiskunde is die vraag na die aard van matematiese entiteite en hulle verhoudings. As die Wiskunde sy aanspraak om erkenning as deel van die wetenskap wil handhaaf, moet dit bestaan uit oordele aangaande 'n deel van die werklikheid. Die wetenskap soek immers kontak met die werklikheid waaroor dit geldige oordele wil formuleer. Die Wiskunde maak dus anspraak op waarheid, d.w.s. die oordele van die Wiskunde moet ooreenstem met die gegewens wat daardie bepaalde deel van die werklikheid bied. Voordat bepaal kan word wat hierdie watarheid, waarop die Wiskunde aanspraak maak, eintlik is, moet ons weet waaroor die oordele van die Wiskunde gaan, m.a.w. dic vraag na die ard, en in besonder die synswyse van die wiskundige entiteite en die verhoudings wat daartussen hestaan, moet heantwoord word.

In hoofsaak is daar drie beskouinge ganghaar oor die aard van matematiese entitcite. Dic eerste is ' $n$ realishlese beskouing wat aan die matematiese entiteite 'n bestaan buite en onafhanklik van ons bewussyn, d.w.s. buite ons waarneming en denke, toeken. Vir dic realis is die wiskundige stellings waar in soverre hulle beantwoord aan hierdie aanvaarde hestaan van die wiskundige entiteite.

Die tweede is ' $n$ idealistiese beskouing wat die matematiese entiteite sien as denkobjekte, denkinhoude of denkkonstruksies. Die matematiese entiteite is begrippe van die menslike denke en het geen hestaan onafhanklik van ons kemne nie. Die idealisme leer immers dat die mens nooit 'n op sigself staande werklikheid ken nie dog slegs dit wat in sy bewussyn as voorstelling of idee gegee is of deur die denke as sodanig gekonstrucer is. Dit sien kennis eintlik as selfkennis van die menslike verstand.*

* Vir die doeleindes val hicrdic rede beskon ons slegs die kenteoretiesc idealisme. 
Die Intuïsionistiese Wiskunde van Brouwer, wat die hele Wiskunde wil konstrueer uitgaande van 'n basiese intuïsie van temporale suksessie, is geïnspireer deur 'n geloof in die idealisme, minstens ly Brouwer self. Op grond van hierdie basiese intuïsie is die natuurlike getalle kenbaar, volgens Brouwer. $O_{\mathrm{p}}$ die natuurlike getalle word dan voortgehou deur alle verdere wiskundige entiteite uit die natuurlike getalle te konstrueer. Dit bring mee dat in die versamelingsteorie 'n versameling nie beskou word as 'il vooraf gegewe veelheid van elemente nie, maar dat die elemente van in versameling gekonstrueer of opgebou moet word uit die materiaal gebied deur die natuurlike getalle, volgens 'n vaste reël. In eksistensiebenyse moet die entiteit gekonstrueer word alvorens die hestaan daarvan a angeneem word, en is dit nie voldoende om aan te toon dat die anname van die nie-hestaan van die entiteit tot 'n kontradiksie lei nie. Ook hierdie eis van konstrueerbaarheid by Brouwer hou verband met sy idealistiese uitgangspunt.

Dit is byna onnodig om te vermeld dat in die versamelingsteorie die ou universialiastryd tussen die nominalisme en die realisme weer tevoorskyn tree. Die nominaliste gee voor dat hulle nie weet wat anders met 'n versameling bedoel word nie as dat dit slegs 'n naam i; waarmee 'n aantal individuele dinge willekeurig saamgevat word. Ook die konseptualisme (wat nominalisme in ruimer sin is) erken slegs individuele dinge wat dan in begrippe saamgevat word. Vir die nominalisme in enger $\sin$ sowel as die konseptualisme geld dat wat werklik bestaan slegs individuele dinge is wat aan niks algemeens deel het nie. Die realiste daarenteen aanvalar dat die algemene onafhanklik van die menslike denke bestaan.

'n Derde beskouing is die formalisticse, waarin daar gestreef word om filosofiese voorveronderstellings tot 'n minimum te beperk en wat deur sommige skrywers geïnterpreteer word as verenigbaar met byna cnige soort lilosofie, omdat dit die Wiskunde wil ontwikkel as 'n suiwer formele deduktiewe teorie wat nie gebonde is aan enige bepaalde betekenis wat geheg kan word aan die simbole in hierdie formalisme nie.

Dit hoef nouliks vermeld te word dat by wiskundiges alle moontlike skakerings en samestellings van bogenoemde beskouings aangetref word. Wiskundiges is miskien berug vir die gemak waarmee hulle van een sienswyse wissel na 'n ander, en daar is maar weinig wiskundiges wat hulle hele lewe lank standvastig aan een filosofiese uitgangspunt trou was. Brouwer kan genoem word as een van die vernaamste uitsonderings. Die vernaamste rede vir hierdie wisselvalligheid is dat dit in die Wiskunde moontlik is om, vanweë sy beperkte aantal aannames, die implikasies van die grondliggende aannames fyn uit te pluis. Die eensydigheid van 'n bepaalde uitgangspunt blyk dan konsekwensies te hê wat nie strook met ander gegewens nie, sodat die wiskundige ontrou word aan sy eie uitgangspunt, wat hom dan 'n ander een laat aanneem. 
Die bedoeling is om in hierdie rede slegs die formalistiese beskouing ietwat uitvoerig toe te lig en enkele implikasies daarvan aan te dui.

Sowel die Wiskunde as die Logika toon in hulle opbou duidelik onderskeibare strukture. Hierdie strukture word bepaal deur die relasies wat bestaan tussen die wiskundige entiteite onderling en die logiese entiteite onderling.

Die moontlikheid tot 'n formalisering van die Wiskunde en die Logika is m.i. nou daarin geleë dat hierdie strukture deur middel van tekens grafies weergegee kan word, waarby afgesien word van enige spesifieke hetekenis wat die tekens mag hê. Hierdie weergawe word verder verwesenlik deur bepaalde omvormingsrë̈ls voor le skryf waarvolgens met die tekens geopereer mag word.

Deurdat die formalis die Wiskunde eintlik reduseer tot 'n studie van die struktuur van die wiskundige entiteite t.o.v. hulle onderlinge relasies en die struktuur van die deduktiewe uithou van die Wiskunde, is dit ook begryplik waarom hy meen dat 'n formalistiese uitbou van die Wiskunde verenigbaar is met verskillende filosofiese voorveronderstellings. Verskillende voorveronderstellings sal verskillende Wiskundes tot gevolg hê. Tog kan hierdie Wiskundes, t.o.v. die beskoude entiteite en in hulle deduktiewe opbou, nog isomorfe strukture vertoon sodat die formalis, wat hierdie struktuur uit die Wiskunde abstraheer, die uitgangspunte onbelangrik vind. Die volgende uitspraak van Russel, in kritiek op idealistiese en realistiese uitgangspunte, werp lig op hierdie beskouing: "There has been a great deal of speculation in traditional philosophy which might have been avoided if the importance of structure, and the difficulty of getting behind it, had been realised. For example, it is often said that space and time are subjective, but they have objective counterparts; or that phenomena are subjective, lut are caused by things in themselves, which must have differences inter se corresponding with the differences in the phenomena to which they give rise. Where such hypotheses are made, it is generally supposed that we can know very little about the objective counterparts. In actual fact, however, if the hypotheses as stated were correct, the objective counterparts would form a world having the same structure as the phenomenal world ... In short, every proposition having a communicable significance must be true of both worlds or of neither."

In hierdie rede sal ek probeer aantoon dat die formaliste nie aan filosofiese voorveronderstellings kan ontsnap nie en dat daar, vanweë die eensydigheid van hulle uitgangspunt, konsekwensies gevolg het waardeur die formalistiese standpunt, as omvattende verklaring vir die aard van die Wiskunde, dwingend gewysig moet word. Om dit aan te toon, is dit nodig om die formalistiese program vir die Wiskunde uitvoeriger te bespreek en met voorbeelde toe te lig.

Aan u wat bekend is met die Algebra, soos dit op hoërskool geleer 
word, sal dit duidelik wees wat die bedoeling is as beweer word dat die lormalis in sy diepste oortuig is dat simbole of tekens en allerlei bewerkinge, uitgevoer op hierdie simbole die kern van die Wiskunde is. As u u nog vaagweg kan herinner dat aan u geleer was om „,oorkruis te vermenigvuldig”, ,alles na die linkerkant van die $=$ - teken te bring", ",hakies te verwyder" en dit of dat te "kanselleer", dan het u reeds 'n gedeeltelike formalistiese beïnloeding ondervind.

Hilhert, die vader van die konsekwente formalisme in die Wiskunde, het sy oortuiging so gestel: "Everything which constitutes mathematics today is rigorously formalized, so that it hecomes a stack of formulas". In hoe 'i mate die Wiskunde deur die formaliste in 'n "stack of formulas" romgewerk word, wil ek u illustreer an 'n voorbeeld uit die Meetkunde, liewer as uit die Algebra, omdat ons eerste kennismaking met die Meetkunde gewoonlik nie-formalisties van aard is.

Beskon die volgende vier aksiomas en die daaropvolgende deduksie wat betrekking het op dinge wat ons a's en b's sal noem en voorlopig nie nader sal omskryf nie.

I. Elke h word bepaal deur 'n versameling van a's.

2. Daar hestaan ten minste twee a's.

3. As $a_{1}$ en $a_{2}$ twee a's is, dan bestaan daar een en slegs een $b$ wat deur hulle hepaal word.

4. Vir elke b is daar 'n a wat nie medebepalend is vir b nie.

Alleiding: Daar bestaan minstens drie b's.

Bewys: Daar hestaan minstens 2 a's; noem hulle $a_{1}$ en $a_{2}$ (aksioma 2 ).

Hulle bepaal 'n $b_{\text {, sê }} h_{1}$ (aksioma 3 ).

Iaar hestaan 'n a, sê $a_{3}$, wal nie medehejalend is vir $b_{1}$ nie (aksioma 4 ).

$a_{1}$ en $a_{3}$ hequal ' $n$ b, sê $h_{2}$ (aksioma 3 ). $b_{2}$ is nie dieselfule as $h_{1}$ nie, want $a_{3}$ is nie medebepalend vir $b_{1}$ nie (aksioma $J$ ).

Op dieselfde manier kan angetoon word dat $a_{2}$ en $a_{3}$ 'n lo bepaal wat verskillend is van $b_{1}$ en $b_{12}$.

Hierdie aksiomas en afleiding is vir verskillende interpretasies vatlaar. Iatat die a's mense wees en die b's verenigings waaraan hulle behoort. Dje aksiomas ken dan die volgende eienskappe aan die verenigings en mense toe:

1. Elke vereniging word hepaal deur 'n versameling mense.

2. Daar hestaan ten minste twee mense.

3. As $a_{1}$ en $a_{2}$ mense is, dan word een en slegs een vereniging deur hulle bepaal.

4. Vir elke vereniging is daar 'n persoon wat nie aan die vereniging behoort nie.

Die afleiding is dan dat daar minstens drie verenigings bestaan. 'n Ander voor die hand liggende interpretasie is om die a's die drie 
hoekpunte van 'n driehock, en die b's die drie sye van die driehoek te laat dandui.

Hierdie enigsins triviale stukkie Wiskunde moet dien om twee belangrike eienskappe van die Wiskunde warop) die formaliste bou, te illustreer. In die eerste plek is dit duidelik dat die deduksie op generlei wyse afhang van enige spesifieke betekenis wat aan die simbool a en b toegeken word nie en dat die enigste betekenis nat hulle het, bepaal word deur die aksiomas. Die (weede eienskap) is die uitsluitlike beroep) wat op die Logika gedoen word om tot in resultat te kom op grond van die aksiomas. Om fot in hegrip van die formalisering van die Wiskunde te kom, word hierdie vier aksiomas nou geanaliseer. Behalwe die sg. ongedefinieerde terme, in hierdie geval dic a's en b's, kom daar terme in die aksiomas voor wat na die gebied van die logika verwys kan word. Hulle is die woorde en frases ,elke', ,word hepaal', ,versameling", ,daar bestaan', ,as... dan ...', , dan en slegs dan', ,nie' ens.

Behalwe hicrdic woorde kom nog die woorde, een', ,twee' en ,drie' voor wat betrekking het op 'n ander vertakking van die Wiskunde waarvan die formalisering nie nou ter sprake is nie.

Om tot 'n volledige formalisering van die Wiskunde te kom, is dit dus ook nodig om die Logika om te skep in 'n formele calculus, d.w.s. om to skep in „a stack of formulas" waarmee op hepaalde voorgeskrewe manier gereken moet word. Beskou die volgende logiese hewering: „Die punt a lê op die lyn bof hy lê nie op lyn h nie". Die bewering is 'n spesiale geval van die logiese stelling $p$ of nie-p. Ons kom tot die aangehaalde hewering deur die reël, bekend as die reell van substitusie vir proposisionele veranderlikes, toe te pas, en warvolgens een bewering afgelei kan word uit 'n ander, wat 'n proposisionele veranderlike bevat, deur 'n hepaalde bewering vir hierdie veranderlike te substitueer. In hierdie geval is die bewering: , punt a lê op lyn b", gesubstitueer vir $p$ in die hewering ,p of nie-p".

In die gewone gang van sake gebruik die wiskundige logiese reëls en stellings min of meer as selfevidente gegewens. Die analise waardeur hierdie reëls blootgelê is en luulle onderlinge samehang aangetoon is, het met Aristoteles hegin maar is eers gedurende die einde van die vorige eeu en in hierdie eeu deur wiskundiges en logici soos Boole, Frege, Russel e.a. tot volle wasdom gebring.

In die laaste honderd jaar het die Logika ontwikkel in 'n wetenskap wat sterk herinner aan die wiskundige wetenskappe en dit het belangrike bydraes gelewer tot die oplos van probleme i.v.m. die Wiskunde as deduktiewe stelsel, in teenstelling met Aristoteliaanse logika wat feitlik naardeloos as hulpmiddel by die Wiskunde is. Hedendaags is die Aristoteliaanse Logika slegs 'n hrokstuk van die Logika. Die nuwe Logika het baie belangrike insigte gebied aangaande deduktiewe stelsels in die algemeen en die Wiskunde in die besonder. 'n Enkele resultaat in hierdie 
verband sal nog genoem word. As illustrasie van 'n geformaliseerde logika word die deel van die Logika hekend as die Logika van volsinne of die Proposisielogika, gel,ruik. Dit is 'n deel van die Logika wat besonder helangrik is vir die Wiskunde.

Sinne word aangedui deur letter ,j', ,q', ,r', ens., en hierdie letters nord veranderlikes genoem. Dan word twee basiese, sg. ongedefinieerde simbole, ,v' en , $\backsim$ ', ingevoer wat staan vir die woorde, of' en ,nie'. Hierdie twee simbole heet konstantes, omdat hulle steeds dieselfde woorde aandui in alle formules. Die begrip implikasie : as p dan q; in simbole : I $\supset$ I, word gedefinieer as $\backsim p$ v q, d.w.s.

$$
(p \supset q)=(\sim p v q) \text {. }
$$

Die woord ,en" word angedui deur die simbool, .' en die sin p.q word gedefinicer as

$$
\sim(\sim p \vee \sim q)
$$

Vir die Proposisielogika geld verder sg. formasiereëls, waarvolgens uit hierdic simbole formules gevorm kan word wat normaalweg die vorm van sinne sou hê. Twee transformasiereëls word angeneem vir dic Proposisielogika. l)ie cerste is die reeds genoemde sulstitusiereël, waardeur uit ren formule 'n volgende afgelei mag worl deur vir 'n bepaalde volsinveranderlike deurgaans dieselffe formule te substitueer. Die tweede reël $i$; die sg. modlus ponens-reël, warvolgens uit die formule.$S_{1}$ en die formule, $S_{1} \supset S_{2}{ }^{\prime}\left(S_{1}\right.$ impliseer $\left.S_{2}\right)$ altyd dic formule , $S_{2}{ }^{\prime}$ a fgelei kan word.

T'en slotte word daar vier aksiomas vir lie Logika van volsinne neergelê, nl.

1) (p $\vee p) \supset p .(\Lambda s$ ons vir $p$ die $\sin$, dit is vanaand koud' substitueer, dan lui hierdie aksioma: As dit vanaand koud is of dit is vanaand koud dan is dit vanaand koud).

2) $p \supset(p \vee q)$

(Bv.: As dit vanaand koud is dan is dit vanaand koud of my naam is nie Hendrik nie).

3) ( $p \vee$ q $) \supset(q \vee p)$

(Bv.: $\Lambda \mathrm{s}$ dit vanaand koud is of hierdie rede is te lank dan is hierdie rede te lank of dit is vanaand koud).

4.) $(p \supset q) \supset((r \vee p) \supset(r \vee q))$

(Bv.: Die implikasie, $\Lambda$ s dit reën dan is die wêreld nat' impliseer die implikasie,$\Lambda$ s die son skyn of as dit reën dan skyn die son of die wêreld is nat').

Uit hierdie vier aksiomas word met behulp van die genoemde fundamentele reëls alle stellings in die Proposisielogika afgelei. Ek noem net drie:

1) $\sim \mathrm{p} \mathrm{vp}$ (Bv.: Die aarde is rond of dic aarde is nie rond nie).

2) $\sim p) \supset(p \supset q)$. Dit is die effens paradoksale resultaat van die Proposisielogika dat 'n onware hewering enige bewering implisecr. 
3) $\sim(p . \backsim$ p) (Bv.: Dit is nie waar dat die aarde rond is en dat die aarde nie rond is nie).

Terloops word opgemerk dat uit die twee laasgenoemde stellings volg dat as in ' $n$ formele deduktiewe stelsel twee strydige formules albei as geldig aangeneem word, d.w.s. 'I formule $\Lambda$ sowel as die formule nic- $\Lambda$, dan is alle proposisies bewyshaar in die stelsel. Son bv. aangeneem word dat die aarde rond sowel as nie rond is nie, dan is dit moontlik om volgens die reëls van die Proposisielogika af te lei dat president Swart koning van Rusland is. Poincaré, wat geen ondersteuner van die formaliste se program was nie, het hieroor die volgende te sê gehad: „Mr Russell arrives at the conclusion that a false proposition of any kind involves all the other proposotions, whether true or false. M. Couturat says that this conclusion will appear paradoxical at first sight. However, one has only to correct a bad mathematical paper to recognize how true Mr Russell's view is. The candidate often takes an immense amount of trouble to find the first false equation; lut as soon as he has ohtained it, it is no more than child's play for him to accumulate the most surprising results, some of which may actually be correct".

Hierdie resultaat van die heer Russell dring egter dadelik cen van lie sentrale probleme vir elke deduktiewe stelsel aan ons aandag op, nl. hoe bepaal mens met sekerheid of die aksiomas ten grondslag van die deduktiewe stelsel strydig is of nie? Hoe kan mens met sekerheid hepaal dat dit nie moontlik sal wees om 'n stelling $\Lambda$ en ook die stelling nie-A, alleei deur logiese redenering uit die stelsel aksiomas af te lei nie? Dat dit 'n ingewikkelde probleem kan word, is duidelik as mens bedink dat die aksiomatisering van die Euklidiese Meetkunde om en by die 20 aksiomas vereis. Voordat ons egter ingaan op die probleme wat 'n deduktiewe sisteem as sodanig stel, wil ek, resumerend, die aard van die formalistiese program kort stel. Jie formalis aanvaar die aksiomaties-deduktiewe aard van die Wiskunde. Dit is duidelik dal as die logiese deduksie in 'n wiskundige bewys self as 'n aaneenskakeling van formules voorgestel kan word, die Wiskunde inderdaad volkome geformaliseer kan word. $\Lambda$ an die een kant het ons nou 'n aantal aksiomas, sê met betrekking tot die Mcetkunde. Die aksiomas gaan egter oor ongespesifiseerde dinge, oor a's en b's, wat slegs betekenis het in soverre die aksiomas bepaalde relasies neerlê vir die moontlike dinge waarvoor hierdie simbole mag staan. Hierdie betekenis is egter afhanklik van woorde waarvan die betekenis op logiese terrein lê. Maar die Logika self is nou geformaliseer en die woorde is vervang deur simbole walamee geopereer kan word volgens vasgestelde reëls, sonder om maar een oomblik te dink aan enige betekenis wat die simbole magr hê. Bo die aksiomas van die Meetkunde, in hulle geformaliseerde vorm, lê dus nou die aksiomas van die Logika self, ook geformaliseer, met die bepaalde bewerkingsreëls wat gelıandhaal moet word. Inderdaad wil dit nou voorkom of op hierdic manier die liele 
Wiskunde een simbolespel word, waarly die wiskundige geen aandag meer hoef tc gee aan enige betekenis wat aan die simbole mag toegeken word nie, maar waarby hy slegs aandag hoef te gee aan watter formule in die plek van ' $n$ ander gesubstitueer mag word en watter formule van die ander afgeskei mag word volgens die modus ponens-reël, met toepassing van die aksiomas van dic Logika sowel as van die Meetkunde. Hilbert, die ontwerper van die program. stel dit so (aangehaal deur Wilder): ..Everything which constitutes mathematics today is rigorously formalized, so that it becomes a stack of formulas. These distinguish themselves from the ordinary formulas of mathematics only by the fact that besides the ordinary signs or symbols there enter also the symbols of logic, especially implication $(\supset)$ and negation $(\backsim)$. Certain formulas which serve as foundation stones for the formal edifice of mathematics are called axioms. A proof is a figure, which must lie clearly before us as such; it consists of conclusions by means of the conclusion scheme

$$
\begin{aligned}
\text { (If) } & S \\
\text { (and) } & S \underset{T}{D} \text { 'T', }
\end{aligned}
$$

where the prenise, $S$, is either an axiom (or axioms) or the end formula of a proof figure which occurred earlier in the development. $\Lambda$ formula is called provable if it is either an axiom or the end formula of a proof.

To the ordinary, thus formalized mathematics, is added, in a certain sense, new mathematics, a metamathematics... In this metamathematics one works with the proofs of ordinary mathematics, these latter themselves forming the object of investigation".

Hierdie laaste opmerking van Hilhert is belangrik en verdien nadere toeligting. Behalwe die formules wat in die deduktiewe stelsel afgelei kan word, kan daar ook uitsprake oor hierdie formules gedoen word. Hierdie uitsprike oor die formules in die dedukticwe sisteem verwys Hilbert nou na 'n nog hoër liggende vlak, nl. die vlak van die Metamatesis. Die uitspratak: „I)ic formule A is lelik" of "Die formule A is onsimmetries" is dus metamatematiese uitsprakc. Ook dic reëls wat voorskryf hoe met die simbole in die formele stelsel geopereer moet word, lê op die metamatematiese vlak.

Die hele probleem van die strydigheid of nie-strydigheid van die aksiomas van 'n deduktiewe sisteem lê op die metamatematiese vlak, want dit vra na die afleibaarheid van 'n formule $A$ of die formule nie-A uit die aksiomas van die formele sisteem. Hierdie probleem is byna so oud soos die Wiskunde self. Die vyfde aksioma van die Euklidiese Meetkunde heweer dat as 'n punt en 'n reguit lyn in 'n plat vlak gegee is, met die punt nie op die reguit lyn nie, dan kan daar een en slegs een reguit lyn deur die punt getrek word wat die gegewe reguit lyn nie sny nie. Om een of ander rede het die wiskundiges van die oudheid gedink dat hierdie aksioma uit die ander aksiomas, waarvan die selfevidensie sprekender vir 
hulle was as die vyfde aksioma, afgelei kan word. Na ceue van vrugtelose pogings om die vyfde aksioma van die ander af te lei, is (hoofsaaklik deur die werk van Gauss, Bolyai, Lobachevsky en Riemann) daarin geslaag om die onmoontlikheid van so 'n afleiding te bewys. Hierdeur het dit duidelik geword dat die Euklidiese Meetkunde nie die enigste moontlike Neetkunde is nie, maar dat ander Mectkundes opgebou kan word deur van ander aksiomastelsels uit te gaan, wat wel resultate strydig met die Euklidiese Meetkunde sal oplewer maar wat self nie onderling strydige resultate sal bevat nie. In die Riemannse Meetkunde word die vyfde postulaat van die Euklidiese meetkunde bv. vervang deur die postulaat dat deur 'n gegewe punt buite 'n reguit lyn geen parallelle lyn aan hierdie lyn getrek kan word nie. Die vraag is nou: Is die aksiomas van die Riemannse Meetkunde strydig of nie? Dit is duidelik dat die probleem nie opgelos kan word deur maar stelling na stelling af te lei en aan te toon dat hulle nie strydig is nie, want die sekerheid hestaan nie dat die volgende stelling nie in teëspraak met een van die voriges sal wees nie. Die hele moontlikheid van die bestaan van nie-Euklidiese Meetkundes hang dus saam met die probleem van nic-strydigheid van aksiomastelsels.

Die probleem is aanvanklik verhelp deur die konstruksie van modelle vir die stelsel abstrakte postulate, op sodanige wyse dat elke postulaat 'n ware bewering word met betrekking tot die model. Die nie-strydigheid van die Riemannse Meetkunde kan aangetoon word deur 'n model soos volg te konstrueer. Die woord, vlak' in die Riemannse aksiomas word geïnterpretecr as 'n boloppervlak, die woord ,punt' as 'n punt op die boloppervlak en die woorde, reguit lyn' as 'n grootsirkel op die boloppervlak ens. Aangesien die aksiomas waar is vir hierdie model, is dit oënskynlik selfevident dat daar ook geen strydige afleidings uit die aksiomas gemaak kan word nie. Die ongeluk is egter dat hierdie model van sirkels en punte op 'n boloppervlak bestudeer moet word volgens die aksiomas van die Euklidiese Mectkunde, sodat die nie-strydigheid van die Riemannse Meetkunde afhanklik gemaak is van die nie-strydigheid van die Euklidiese Meetkunde. Die problecm is dus nic opgelos nie maar slegs verskuif na 'n ander terrein.

Die inherente beperkinge van die modelmetode, en ander oorwegings, het daartoe gelei dat na nuwe weë gesoek is. Die strewe van Hilbert was na 'n ,absolute" bewys van nie-strydigheid van aksiomastelsels, waarin die nie-strydigheid aangetoon $k$ on word sonder om 'n beroep te doen op die nie-strydigheid van ander aksiomastelsels. Die eerste stap) in hierdie strewe was die algehele formalisering van die deduktiewe stelsel. $\Lambda$ s 'n deduktiewe stelsel volledig geformaliseer is, is die afleiding van stellings uit die aksiomas, soos reeds aangetoon, niks meer nie as die transformasie van een string simbole in 'n ander string simbole volgens bepaalde reëls. Daar hestaan dan geen gevaar dat onverantwoorde redenasieprinsipes onbewustelik in die deduktiewe proses ingesmokkel word nie. So 'n 
formele sisteem lê die struktuur van die logiese relasies tussen die verskillende stellings annskoulik bloot. Hilbert het vermoed dat, deur die strukturele eienskappe van so 'i geformaliseerde deduktiewe sisteem noukeurig te hestudeer, angetoon sal kan word dat formeel strydige formules nie kan voorkom in die stelsel nie. Aangesien hierdie studie egter op die metamatematiese vlak lê, sou die hewysvoering oor dergelike probleme ook in metamatematiese taal en, sal ons maar sê, Metalogika moes geskied, d.u.s. wat Hilbert aanbetref in gewone Duits en gewone logika. Aangesien die logici destyds met hulle hande in die hare gesit het oor sekere antinomiee in die Logika, wat gesentreer was om die oneindigheidshegrip, het Hilhert aanvanklik voorgestel dat dergelike bewyse slegs van finitistiese metodes gebruik maak, d.w.s. slegs metodes wat nie verwys na oneindig veel strukturele eienskappe, formules of hewerkings nie sou toelatatbar wees.

Dit mag insiggewend wees om kortliks so '11 nie-strydigheidsbewys van nader te heskou. Daarvoor kies ons 'n geformaliseerde deduktiewe stelsel wat ons reeds heskryf het, nl. die van die Proposisielogika self. I)it kin bewys word dat die aksiomas en alle formules afgelei uit die aksiomas van die Proposisiclogika 'n gemeenskaplike eienskap het, nl. dat hulle toutologië is. Met toutologie word hier bedoel 'n hewering wat geen logiese moontliklede uitsluit nie, hv.: „Die maan is 'n blink koper skottel of die maan is nie 'n blink koper skottel nie". Die formule p $v \backsim$ p bly naamlik waar, wat ons ook al vir p substitueer. Die formule $\mathrm{p} v \mathrm{q}$ is nie 'n toutologie nie en is dus nie 'n stelling van die Proposisielogika nie. Maar nou is reeds vroeër genoem dat, indien uitgegaan word van strydige aksiomas, alle moontlike formules uit dergelike aksiomas afgelei kan word en dus ook die formule $\mathrm{p} \mathrm{v}$ q. I) us is die aksiomas van die Proposisielogika nie-strydig.

'n Tweede prohleem wat op metamatematiese vlak lê en wat kortliks genoem moet word, is die van volledigheid van 'n aksiomastelsel. 'n Stelsel aksiomas heet volledig as elke stelling, geformuleer in die terme van die deduktiewe stelsel volgens die geldige formasiereëls, of sy ontkenning, afleibaar is uit die aksiomas in die deduktiewe sisteem. As nòg die stelling, nog sy ontkenning afleibaar is, dan hect die stelsel onvolledig. lie cnkele aksioma uit dic Euklidiese Meetkunde: „Elke twee punte bepaal 'n reguit lyn", vorm 'n onvolledige stelsel, want dit is duidelik dat die stelling ,Elke twee reguit lyne bepaal hoogstens een punt wat op albei lê", of sy ontkenning. nic op grond van hierdie enkele aksioma bewys kan word nie.

() hierdic stadium kan reeds dic volgende kritick op die formalistiese program gelewer word. Hoewel dit wat gewoonlik die Wiskunde genoem word hehoorlik geformaliseer is in al sy aspekte, het hierdie formalisering 'n nuwe Wiskunde, nl. dic Metamatesis na vore gebring. Wat is nou ' $n$ bewys in die Metamatesis? Dit is duidelik dat die bewys- 
metodes van die geformaliseerde Wiskunde, wat geregverdig moet word in die Metamatesis, nie maar met huid en laar oorgeneem kan word sonder om in sirkelredenerings te verval nie. Die finitistiese eise wat Hilbert stel aan metamatematiese bewyse, bv. dat die bestaan van 'n entiteit eers erken word as dit deur eindige metodes gekonstrueer is, is sterk intuisionisties gekleurd. Ook sy vashou aan die metode van volledige induksie, sover dit die Metamatesis betref, is feitlik 'n onderskrywing van een van die basiese premisse van Brouwer se Intuïsionisme.

Verder het ons reeds vroë̈r gewys op die verband tussen 'n formalistiese opset van die Wiskunde en die strukturele eienskappe van die Wiskunde. Ook die vraag na die metode van keuse van die aksiomas van 'n formele sisteem is van belang in die Wiskunde en dit lê op' 'n terrein anders as die formele. Hierop sal ons egter nie ingaan nie.

Die ingrypendste beperkings inherent aan die Formalisme is egter deur Gödel aan die lig gebring in 'n beroemde geskrif wat in 1931 gepubliseer is. Hierdie werk van Gödel is 'n hoogtepunt in die geskiedenis van die Logika en die Wiskunde, en as voorbeeld van subtiele denke en menslike vernuf is daar weinig ander wetenskaplike prestasies wat die van Godel sal ewenaar. Die bewyse wat Gödel in sy geskrif gee, kan nie verduidelik word sonder om 'n beroep te doen op gevorderde matematiese metodes nie en lier word volstaan met slegs die resultate te noem.

In die eerste plek het hy aangetoon dat as die aksiomas wat geld vir elementêre Rekenkunde nie-strydig is, dan is die aksiomastelsel onvolledig. Dit is reeds genoem dat met volledigheid van 'n stelsel aksiomas bedoel word dat elke formule $A$ wat uitgedruk kan word in die terme van die geformaliseerde deduktiewe stelsel, of sy ontkenning nie-A, logies afleibaar is uit die betrokke aksiomas. Gödel het daarin geslaag om die waarheid van 'n sekere formule in die elementêre Rekenkunde met behulp van metamatematiese argumente te bewys en ook aan te toon dat hierdie formule nie logies afleibaar is uit die aksiomas wat geld vir die elementêre Rekenkunde nie. Verder kon hy aantoon dat al sou hierdie aksiomas aangevul word met nog meer aksiomas, sodat die bepaalde formule wel afleibaar is, dan kan weer ander ware formules gekonstrueer word wat nie afleibaar is uit die aangevulde stel aksiomas nie.

Hierdie resultaat van Gödel het 'n eeue-oue wetenskapsideaal finaal omvergewerp. Reeds uit die tyd van dic Grieke stam die ideaal om die hele wetenskap as een groot deduktiewe stelsel op grond van enkele beginsels op te bou. As dit nou nie ecrs bereik kan word vir 'n onderdeel van die Wiskunde soos die Rekenkunde nie, hoeveel minder dan nie vir die hele Wiskunde en alle wetenskappe nie? Maar nog meer: hierdie resultaat toon ook die prinsipiële onuitvoerbaarheil van die formalistiese program vir die hele Wiskunde aan, want dit toon an dat alle ware Rekenkundige formules nic uit 'n eindige aantal aksiomas, wat eens en vir altyd vasgelê is, afgelei kan word met behulp van 'n geslote stelsel 
deduksiereëls nie. Dit toon verder an dat nie finaal rekenskap gegee kan word van die presiese logiese vorm van geldige matematiese hewyse nie en dat die matematiese bewys nie identies is met die formele aksiomatiese metode nie, soos trouens deur sy vindingryke metamatematiese argumente self aangetoon is. Dit gee meer as 'n vermoede dat die menslike verstand veel meer kan vermag as wat enige rekenmasjien oojt sal kan doen, want die prosesse in so "n masjien is altyd gefundeer op die vaste të̈ls van 'in geformaliseerde aksiomatiese prosedure.

In die tweede plek het Cödel aangetoon dat as die elementêre Rekenkunde nie-strydig is, sy nie-strydigheid nie deur die finitistiese metodes wat Hillert vereis het bewys kan word nie. 1)it gee aan die formalistiese program 'n verdere knou. Want as die nie-strydigheid van die aksiomas van die Wiskunde slegs aangetoon kan word deur metodes wat juis moes regverdig word deur die formalistiese program, dan staan ons presies watr ons was.

Ten slotte kom ons dan terug op die vraag wat matematiese waarheid is. Aangesien die formalis die Wiskunde wil reduseer na bewerkings met simbole, waarby afgesien word van enige spesifieke hetekenis wat aan die simbole toegeken kan word, volg dat op 'n wiskundige stelling, wat deur die formalis gereduseer is tot 'n string simbole, die woord waarheid, in sy gewone betekenis, nie van toepassing is nie. Russel stel dit so: ..Pure mathematics is the subject in which we do not know what we are talking about, or whether what we are saying is true" (aangehaal deur Nagel en Newman). Die enigste soort waarheid waarvoor 'n wiskundige stelling, volgens die formalis, in aanmerking kan kom, is of dit 'n logiese gevolgtrekking uit die aksiomas van dic onderhawige deduktiewe stelsel is of nie.

Gödel se stelling konfronteer ons egter met die treurige feit dat by elke aksiomatisering van selfs die elementêre Rekenkunde daar steeds stellings te vinde is wat nie afleibaar is uit hierdie aksiomas nie, sodat die uiteindelike aksiomatisering van die hele Wiskunde uitgeslote lyk. Frger nog, hy toon aan dat hierdie stellings geldige rekenkundige formules is en dus waar is deur van metodes anders as van die voorgeskrewe aksiomaties-deduktiewe metode gebruik te mak. Enige vaste aksiomatiese benadering tot die getalleteorie kan dus nie alle ware stellings op hierdie gebied te voorskyn bring nie. Nieteenstaande hierdie besware teen die aksiomaties-deduktiewe metode, bly dit nog die mees gebruiklike en vrughaarste metode vir elke vertakking van die Wiskunde. Dat die vraag wat presies matematiese waarheid is, egter nog lank nie besleg is nie, word deur Gödcl se resultate weer skerp na vore gebring.

Op watter omvattende wyse matematiese waarheid gedefinieer moet word om aan die hevinding van Gödel reg te laat geskied, vermoed ek, is 'n vraag wat die wiskundiges nog lank sal hesig hou. Gödel self skyn te 
meen dat slegs 'n terugkeer na in Platoniese realisme die antwoord sal verskaf.

Mag ek kortliks nog in eie standpunt stel, 'n beskouing wat grotendeels met die Wyshegeerte wat aan ons Lniversiteit geleer word ooreenstem en waarmee, in helangrike opsigte, ook die van E. W. Beth oorrenstem. Uit voorgaande en ander resultate in die Wiskunde lyk dit asof deduktiewe teorië̈ nie "n genoegsame heskrywing van die Wiskunde bied nie, en dit lyk waarskynlik dat ons kemnis van die Wiskunde, altans gedeeltelik, "n onmiddellike of intuitiewe aard het. Hieruit volg nie noodwendig dat alle Wiskunde uit sulke kennis bestaan nie of dat die deduktiewe teorieë van die Wiskunde geoordeel moet word on grond van hulle ooreenstemming met ons matematiese intuïsie nie. Eerder ontstaan Wiskunde deur die rasionele verwerking van ons insigte wat gebore is uit hierdie intuisie.

Die mens het vanwë̈ sy lewenservaring 'n onmiddellike kontak met en kennis van die verskillende aspekte van die werklikheid, waarvan ook die matematiese entiteite ' $n$ besondere aspek is of daarop betrekking het. Hierdie aspekte het, nieteenstaande hulle onafskeidelikheid van mekaar, ook 'n groot mate van selfstandigheid, sodat een aspek nie herlei kan word tot 'n ander aspek sonder om ons siening van die werklikheid te verarm, te vervals, dele van die werklikheid buite rekening te laat en die wetenskap) derhalwe geweld an te doen nie. I)ie getalsmatige aspek moet bv. nie gereduseer word tot die logiese nie, en omgekeerd. Ook die strukturele in die werklikheid moet erken word en sy plek gegee word sonder om die matematiese tot slegs struktuur te herlei. Hoe die onderlinge verbande en die soewereiniteit van die verskillende aspekte saamhang, is die taak van die wetenskay om na te gaan. Dit skyn onmoontlik te wees om een aspek van die werklikheid te ondersoek sonder om die ander aspekte daarby te betrek, want al hierdie aspekte is uiteindelik kante van een en dieselfde skepping; kante waarin al die ander kante op 'n bepaalde manier verteenwoordig is. 'n Suiwer Wiskunde in die sin dat dit nie hoef ag te gee op ander aspekte van die werklikheid behalwe die waarop die wiskundige entiteite direk betrekking het nie, is m.i. 'n onbereikbare ideaal. Dit is egter geen pleidooi vir 'n Wiskunde wat nie 'n eie gebied en eie metodes het nie, dus vir' 'n onsuiwer Wiskunde nie. Ek wil hiermee slegs aandui dat die grense tussen die verskillende vakwetenskappe nie so maklik eens en vir altyd vasgelê word nie.

Hierdie beskouing is ook nie bedoel as 'n duidelik omlynde ontologie wat in 'n vasstaande vorm moet dien as 'n onomstoothare grondslag vir die wetenskappe nie. Inteendeel, hierdie ontologie het, wat myself aanhetref, uit 'n wisselwerking tussen al my aspekte van menswees, o.a. my geloofsoortuiging, wetenskaplike vorming en my ervaring in al sy skakeringe, ontstaan. As sodanig is dit my oortuiging, dat waar 'n sodanige ontologie wel as uitgangspunt vir die beoefening van die wetenskap kan 
dien, dit sy skerpere omlyning en verdere verfyning sal vind in die voortskryding van die wetenskap. Die aantoning van die onuitvoerbaarheid van die oorspronklike formalistiese program deur die konsekwente uitwerking van die implikasies van die formalistiese standpunt, is 'n gedeeltelike bevestiging van hierdie oortuiging. Die verskillende opvattings oor wat matematiese waarheid is, is m.i. 'n weerspieëling van die kontakpunte wat die Wiskunde het met verskillende aspekte van die werklikheid, sodat kennis geneem moet word van die eensydige gevatte waarheidsmomente van elk, en die taak van die wiskundige is ook om hier te onderskei en saam te voeg, om so tot kennis te kom van die skepping en van die grootheid van ons Skepper.

Hooggeagte here Lede van die Raad van die Potchefstroomse Universiteit vir Christelike Hoër Onderwys,

Mag ek my waardering uitspreek teenoor u met my benoeming as hoogleraar in die Wiskunde. Ek beskou dit as 'n eer dat u my vir hierdie roeping waardig geag het en ek wil u verseker dat ek al my kragte sal gee om hierdie verantwoordelike taak uit te voer so ver as wat ek genadiglik daartoe in staat gestel word. Ek is bewus daarvan dat hierdie taak nie uitsluitend bestaan uit die oordrag van kennis nie, maar tegelykertyd ook opvoeding van die mens behoort te wees en dat dit 'n wisselwerking tussen onderrig en ondersoek vereis.

Hooggeleerde Professor Van Rooy,

$\mathrm{U}$ het aan my ' $\mathrm{n}$ voorbeeld van toegewyde diens en beginselvaste optrede gestel wat nie deur my geëwenaar kan word nie, maar wat my steeds tot inspirasie sal wees. U wil ek ook graag bedank vir die groot deel wat u aan my vorming as wetenskaplike en as mens gehad het en vir die jare van vriendelike leiding en samewerking wat ek van u geniet het. My innige wens is dat dit aan my gegun sal word om met dieselfde welslae as $u$ te help voortbou op wat $u$ reeds hier gevestig het.

\section{Hooggeleerde Professor Robbertse,}

$\mathrm{U}$ wil ek bedank vir u vriendelike samewerking, erkentlike gesindheid en die kameraadskap wat u my betoon. Aan $u$ is dit te danke dat ek op 'n kritieke stadium in my lewe my studies kon voortsit. Ek verseker u van my hartlike samewerking in alles wat ons gemeenskaplike taak raak.

Here Dosente in die Departemente Wiskunde en Toegepaste Wiskunde,

In die uithouing van ons departemente het elk van $u$ 'n besondere taak waarin u onontbeerlik is. My wens is dat ons, soos in die verlede, ons hegte samewerking sal voortsit en ons taak ook in die toekoms as 'n gemeenskaplike taak sal sien. 


\section{Dames en Here Studente,}

Ek voel my gelukkig om in die geleentheid gestel te wees om u van diens te wees by die bestudering van die Wiskunde. 'Te alle tye sal ek probeer, sover dit in my vermoë is, om a met rad en daad by te staan.

Dames en Here, ek dank u vir u vererende teenwoordigheid en vir u geduldige aandag.

\section{LITERATUURVERWYSINGS}

E. W. Beth: The Foundations of Mathematics. (North-Holland Publishing Co., Ailam, 19.59).

I. M. Bochenski: Die Zeitgenossischen Denkmehoden. (Franche Verlag. Bern, 1959).

II. B. Curry: Oullines of a liormalist Philosophy of Mathemalics. (North-Holland Publishing Co., A ilam, 19.5l).

A. A. Frankel, Y. Bar-flillel: Foundations of Sel Theory. CNorth-llolland Publishing (co., A:dam, 19:38).

F. Nagel. J. R. Newmat: Goedels Proof. p. 1668 van The World of Mathematics deur J. Newman, Jeel 3. (Ceorge Allen and Inwin, londen, 19.56).

Menri Poincaré: Sicience and Method. (Jover Publications lnc.. Londen).

B. Russel: Introduction to Mathematical Philosophy. (George Allen Unwin, Idal., Londen 19.00).

II. (;. Stoker: Beginsels en Metorles in die Wetenskap. (Pro Rege-Pers Bpk., Pot(hefstroom, 1961).

A. Tarski: Inleiding tot de Iogi'a. (N.V. Noord-Jfollandsche Uitgevers Maalschappij, A diam, 1953).

R. I. Wilder: Introduction to the Foundations of Mathenalies. (John Wiley and Sons, Inc., N.Y.). 